\title{
Monitoring bioconcentration of potentially toxic trace elements in soils trophic chains
}

\author{
Anna Chrzan ${ }^{1}$
}

Received: 20 January 2015 / Accepted: 28 March 2016/Published online: 27 April 2016

(c) The Author(s) 2016. This article is published with open access at Springerlink.com

\begin{abstract}
Potentially toxic trace elements (PTEs) may be transferred to plants and consequently enter the food chain. Environmental monitoring of PTEs is important to control their concentrations in the environment and, particularly in farmland soils. The study aims at estimating the concentration of PTEs in the soil, its grass cover and collected soil invertebrates and consequently to investigate the transfer of pollutants in the soil-plant-fauna trophic chain. None of the PTEs was recorded in soil concentrations at levels exceeding the limits defined by the Regulation of the Minister of Environment. Mean concentrations of $\mathrm{Zn}, \mathrm{Pb}$, $\mathrm{Cd}, \mathrm{Ni}$, and $\mathrm{Cu}$ in soil were $55,52,44,23$, and $10 \%$ of the permitted values, respectively. The concentrations of potentially toxic trace elements in soil samples were higher compared to their levels in grass, except for $\mathrm{Cd}$ which was the other way around. Higher concentration of $\mathrm{Cd}$ in grass than in soil may be attributable to direct deposition of metal particulates emitted from motor vehicles on grass, rather than soil along the road. As far as other metals $(\mathrm{Pb}$, $\mathrm{Ni}, \mathrm{Cu}, \mathrm{Zn}$ ) are concerned, concentration in soil was higher than in grass, however, lower than in the fauna. In the investigated meadow, both grass cover and the collected soil fauna accumulated cadmium in largest amounts and incorporated the studied metals in the following order: $\mathrm{Cd}>\mathrm{Zn}>\mathrm{Cu}>\mathrm{Ni}>\mathrm{Pb}$. All considered elements showed greater concentrations (nearly tenfold higher for cadmium) in fauna than grasses.
\end{abstract}

Anna Chrzan

annachrzn871@gmail.com

1 Department of Ecology and Environmental Protection, Institute of Biology, Pedagogical University of Krakow, ul. Podbrzezie 3, 31-084 Krakow, Poland
Keywords Potentially toxic trace elements (PTEs) - Soil · Grass - Soil fauna $\cdot$ Bioconcentration factor

\section{Introduction}

Soil occupies a basic role for humans because the survival of man is tied to the maintenance of soil productivity, but soil is also the main source of trace elements for plants both as micronutrients and as pollutants (Kabata-Pendias 2011). Trace elements may be transferred in the soil-plantfauna trophic chain and to be toxic at high concentrations.

In the last decades, an increase of concentrations of potentially toxic trace elements (PTEs) has been recorded in all ecosystems, including farmlands. According to numerous studies, the pollution sources of PTEs in environment are mainly derived from anthropogenic sources (Hooda 2010). However, the anthropogenic sources of potentially toxic trace elements in agricultural soils include mining, smelting, waste disposal, urban effluent, vehicle exhausts, sewage sludge, pesticides, fertilizers application and so on (Wei and Yang 2010). In an ecological aspect, contamination may have a significant negative impact on soil as habitat for numerous soil organisms and plants (Ayodele and Oluyomi 2011; Boshoff et al. 2014; Dalenberg and Driel 1990; Heikens et al. 2001; Holoubek et al. 2009; Kelepertzis 2014; Martínez-López et al. 2014; Notten et al. 2005; Weggler et al. 2004; Zhang et al. 2015).

PTEs transmitted to soil as chemical pollutants, are basically irremovable and may only change their form (conversion to other chemical compounds or immobilization due to strong fixation by soil) (Kabata-Pendias 2004, 2011). Consequences of soil contamination with potentially toxic trace elements are rarely observed immediately and are rather likely to cause delayed adverse ecological 
changes. What is important is that PTEs, opposite to other harmful substances, are non-biodegradable and can be only biotransformed in complex physico-chemical and biological processes taking place in the soil (Czech et al. 2014; Hooda 2010).

Fixation of most potential toxic trace elements increases strongly at $\mathrm{pH}$ close to neutral. As the sorption capacity of soil is exceeded, toxicants may be transferred to its arable layer and therefore impose a serious threat to arable crops and, after being incorporated into food chains, to animals and people (Boshoff et al. 2014; Bur et al. 2012; (KabataPendias 2004, 2011); Wojciechowska-Mazurek et al. 2010). Elements such as $\mathrm{Cd}, \mathrm{Pb}, \mathrm{Cu}, \mathrm{Ni}$, and $\mathrm{Zn}$ pose a serious threat to the environment (Hooda 2010; KabataPendias and Mukherjee 2007). The herein discussed potentially toxic trace elements vary strongly in their toxicity. While lead and cadmium are considered toxic, zinc and copper are microelements harmful only in excess values and beneficial at lower levels, necessary for proper functioning of organisms. For the above reason, it is important to monitoring PTEs concentrations in environments, particularly in farmlands.

As the pollutants are harmful for living beings, in many countries their environmental levels are constantly monitored (Aelion et al. 2009; Carlon et al. 2007; Siebielec et al. 2013; Soil Quality Standards for Trace Elements 2011; Wei and Yang 2010).

In particular, farmland soils (nearly $60 \%$ of all soils in Poland), used primarily for production of plant food and animal fodder, should be protected, especially if they are located in areas affected by local pollutant emitters (Maliszewska-Kordybach et al. 2013; Niesiobędzka 2012). Highest potentially toxic trace elements accumulation has been reported for soils and plants located at distances of $20-40 \mathrm{~m}$ from roads. Levels of potentially toxic trace elements decrease as the distance between an agricultural area and a road increases and at 100-150 m they become low (Aelion et al. 2009; Kabata-Pendias and Mukherjee 2007). Therefore, potentially toxic trace elements concentrations in soil, grass and soil fauna were studied at $20 \mathrm{~m}$ from road.

The study aimed at investigating the effects of transportation-generated pollutants on soil habitats. The preliminary research involved comparison of accumulation of selected elements in the grass cover and bodies of soil invertebrates as well as analysis of the transfer of potentially toxic trace elements in the soil-plant-fauna trophic chain of farmland soils situated near local roads, on the example of the district of Bochnia, Poland. This research will be continued.

\section{Materials and methods}

The study area was situated ca. $30 \mathrm{~km}$ to the south-east of the center of Kraków, in Nieszkowice Wielkie within the Bochnia district $\left(49.9500^{\circ} \mathrm{N}, 20.3333^{\circ} \mathrm{E}\right)$.

The research was performed on a meadow located ca. $20 \mathrm{~m}$ from the Uszew-Nowy Wiśnicz road, No. $1444 \mathrm{~K}$ (Poland). This road serves as an alternative transport route between Kraków and Nowy Sącz within the Bochnia district, and is heavily used by cars, trucks and agricultural machinery. The traffic volume reaches an average of 3000 vehicles a day.

Soil samples were collected from the surveyed positions with $25 \mathrm{~cm} \times 25 \mathrm{~cm}$ soil in $1 \mathrm{~m}^{2}$ surface area. The frame was thrust into the soil on the depth of $10 \mathrm{~cm}$. From these samples pedofauna was extracted using the dynamic method with a modified Tullgren apparatus (Murphy 1962).

Samples collected in the meadow included grasses, dried prior to identification of potentially toxic trace elements. Grass cover of the meadow comprised mainly perennial ryegrass Lolium perenne L., timothy grass Phleum pratense L. and smooth meadow-grass Poa pratensis L.

Concentration of potentially toxic trace elements in soil, dry grass and soil fauna was determined by Buck Scientific 200A Flame Atomic Absorption Spectrophotometer after previous preparation of samples. For this purpose, animals, grass and soil samples were dried at $105^{\circ} \mathrm{C}$ to obtain a dry weight. Then, c. a. $2 \mathrm{~g}$ of dried samples of each type were weighed and underwent the mineralization process in a Velp Scientifica DK-20 mineralizer in concentrated nitric acid at $120{ }^{\circ} \mathrm{C}$.

Then, the resulting solutions were poured into measuring flasks filled with distilled water up to $10 \mathrm{ml}$. In the solutions prepared by this procedure, concentration of cadmium, lead, nickel, copper and zinc were determined in a Flame Atomic Absorption Spectroscopy (FAAS) instrument.

The basic FAAS analytical technique parameters (wave, slit width, lamp current oxide flow, fuel flow, LoD, LoQ, recovery) are presented in Table 1 . Reference material was BCR-185, Bovin Liver.

Moisture content, organic matter, organic carbon concentration, $\mathrm{pH}$ and the texture of the investigated soils were determined as well. The $\mathrm{pH}$ of soil was measured using a WTW 330/SET-1 pH meter (Wissenschaftlich-Technische Werkstätten 82362 Weilheim).

Soil humidity was assessed with the gravimetric (dry weight) method. 
Table 1 Basic FAAS analytical technique parameters

\begin{tabular}{|c|c|c|c|c|c|c|c|}
\hline Metal & Wave (nm) & Slit width (nm) & $\begin{array}{l}\text { Lamp current } \\
\text { oxide flow (mA) }\end{array}$ & LoQ (mg/kg) & $\mathrm{LoD}(\mathrm{mg} / \mathrm{kg})$ & Recovery (\%) & Fuel flow \\
\hline $\mathrm{Cd}$ & 228.80 & 0.70 & 4.00 & 0.033 & 0.011 & 103.2 & A-Ac \\
\hline $\mathrm{Cu}$ & 324.80 & 0.70 & 4.00 & 0.035 & 0.012 & 99.6 & $\mathrm{~A}-\mathrm{Ac}$ \\
\hline $\mathrm{Ni}$ & 232.00 & 0.20 & 5.00 & 0.050 & 0.017 & 96.2 & $\mathrm{~A}-\mathrm{Ac}$ \\
\hline $\mathrm{Pb}$ & 217.00 & 0.70 & 4.00 & 0.083 & 0.027 & 102.5 & A-Ac \\
\hline $\mathrm{Zn}$ & 213.90 & 0.70 & 5.00 & 0.069 & 0.023 & 107.3 & $\mathrm{~A}-\mathrm{Ac}$ \\
\hline
\end{tabular}

Wave wavelength (nm), $A-A c$ air-acetylene, $L o Q$ limit of quantitation, $L o D$ limit of detection

Table 2 Summary statistics of some soil properties (number of samples $=6$ )

\begin{tabular}{lrrrlrc}
\hline Properties & Min & Max & Mean & Standard deviation & Median & Skewness coefficient \\
\hline pH (-) & 5.87 & 6.27 & 6.04 & 0.17 & 6.01 & 0.98 \\
Moisture (\%) & 23.45 & 25.77 & 24.91 & 1.06 & 25.09 & -0.97 \\
Organic matter (\%) & 3.02 & 5.69 & 4.19 & 1.13 & 4.02 & 0.74 \\
Sand (\%) & 18.50 & 30.10 & 23.56 & 4.87 & 23.20 & 0.38 \\
Silt (\%) & 29.80 & 35.60 & 31.97 & 2.71 & 31.25 & 0.99 \\
Clay (\%) & 40.52 & 47.81 & 44.47 & 3.02 & 44.77 & -0.57 \\
\hline
\end{tabular}

A given amount of freshly collected soil was weighed and afterwards dried at $105{ }^{\circ} \mathrm{C}$ until mass stabilization. Water content was calculated as difference between the mass of a fresh soil sample and its dry mass (Ostrowska et al. 1991). The areometric method (compliant with PN-R04032 standards), in which the mass percentage content of particular grain-size fractions (groups of soil particles with similar grain size) is measured, was used to analyze the texture of soil and its grain-size composition (Ostrowska et al. 1991).

Organic carbon content was measured by the Tiurin method at the Regional Chemical-Agricultural Station in Kraków (Ostrowska et al. 1991).

Mobility of potentially toxic trace elements in plants and soil invertebrates was assessed with the bioconcentration factor (BCF). BCF values indicate the capability of plants to absorb potentially toxic trace elements from soil and provide information on the translocation of elements from soil solution to the overground parts of plants (Czech et al. 2014). BCF is the ratio between the concentration of a given metal in grass, collected in the meadow, and soil. Analogously, for soil fauna BCF was calculated as a ratio between the concentration of each considered metal in animal bodies and soil.

The arithmetic mean, standard deviation, median and variation coefficient were calculated for concentrations of the considered PTS in meadow soil, grass cover and bodies of soil fauna as well as for the BCF determined for PTS in grass and fauna (Sokal and Rohlf 1995).

The differences between the concentration of potentially toxic trace elements-cadmium, lead, nickel, zinc, and copper in meadow soil, soil fauna and dry grass were calculated.

The distribution of the data was assessed with the Shapiro-Wilk test. For variables showing normal distribution $R$ Pearson correlation coefficients were calculated. For data with non-normal distribution, the Spearman's test was applied (Sokal and Rohlf 1995).

In all analyses, the significance level was established at 0.05. All the calculations were performed using Microsoft Excel 2011 PL and SPSS Statistics 22 computer program.

\section{Results and discussion}

Main physico-chemical features of soil were presented in Table 2. According to the mass percentage content of the sandy, silty and clayey fractions in fine earth, the studied soil was classified as moderately silty loam.

The soil displayed a slightly acidic $\mathrm{pH}$, varying between 5.87 and 6.27 (mean: 6.04), and mean content of organic matter (affecting PTE accumulation) of 4.19 (Table 2).

Basic statistics of the concentrations of some potentially toxic trace elements $(\mathrm{Cd}, \mathrm{Pb}, \mathrm{Ni}, \mathrm{Cu}$, and $\mathrm{Zn})$ in soil, in dry grass and in soil fauna are reported in Table 3.

Soil concentrations of the potentially toxic trace elements did not exceed standard values defined for farmlands (group B) in the Regulation of the Minister of Environment (2002).

The highest concentration $\left(208.63 \mathrm{mg} \mathrm{kg}^{-1} \mathrm{dm}\right)$ was recorded for $\mathrm{Zn}$, while content of other PTEs decreased in the following order: $\mathrm{Pb}>\mathrm{Cd}>\mathrm{Ni}>\mathrm{Cu}$. 
Table 3 Summary statistics of the analyzed potentially toxic trace elements $\left(\mathrm{mg} \mathrm{kg}^{-1}\right)$ in soil, grass and soil fauna (number of samples $=12$ )

\begin{tabular}{|c|c|c|c|c|c|}
\hline \multirow[t]{2}{*}{ Elements } & \multicolumn{5}{|c|}{ Metal concentration } \\
\hline & $\mathrm{Pb}$ & $\mathrm{Cd}$ & $\mathrm{Ni}$ & $\mathrm{Zn}$ & $\mathrm{Cu}$ \\
\hline \multicolumn{6}{|l|}{ Meadow soil } \\
\hline Mean & 51.85 & 1.76 & 23.23 & 164.47 & 15.41 \\
\hline Min & 47.54 & 1.34 & 18.33 & 123.43 & 14.81 \\
\hline Max & 53.44 & 2.20 & 27.81 & 208.63 & 17.14 \\
\hline Standard deviation & 2.38 & 0.35 & 3.19 & 34.99 & 0.96 \\
\hline Median & 53.11 & 1.67 & 23.78 & 163.51 & 14.85 \\
\hline Skewness coefficient & -1.56 & 0.39 & -0.25 & 0.09 & 1.55 \\
\hline Range of values & $100^{\mathrm{a}}$ & $4^{\mathrm{a}}$ & $100^{\mathrm{a}}$ & $300^{\mathrm{a}}$ & $150^{\mathrm{a}}$ \\
\hline \multicolumn{6}{|l|}{ Dry grass } \\
\hline Mean & 27.99 & 2.46 & 12.01 & 103.64 & 10.71 \\
\hline Min & 22.23 & 1.99 & 10.97 & 99.99 & 8.21 \\
\hline Max & 34.13 & 3.11 & 13.14 & 109.54 & 13.80 \\
\hline Standard deviation & 4.12 & 0.47 & 0.93 & 3.36 & 2.08 \\
\hline Median & 28.06 & 2.33 & 11.95 & 103.05 & 10.37 \\
\hline Skewness coefficient & 0.13 & 0.47 & 0.15 & 1.13 & 0.46 \\
\hline Range of values & $7-65^{\mathrm{b}}$ & $0.2-2.3^{\mathrm{b}}$ & $3.8-32^{\mathrm{b}}$ & $38-264^{\mathrm{b}}$ & - \\
\hline \multicolumn{6}{|l|}{ Soil fauna } \\
\hline Mean & 71.25 & 19.12 & 35.29 & 740.47 & 38.29 \\
\hline Min & 25.92 & 9.92 & 14.65 & 526.75 & 22.04 \\
\hline Max & 134.91 & 32.93 & 72.92 & 1076.91 & 54.62 \\
\hline Standard deviation & 41.96 & 8.51 & 21.80 & 239.19 & 13.04 \\
\hline Median & 61.56 & 19.39 & 30.30 & 664.77 & 36.41 \\
\hline Skewness coefficient & 0.67 & 0.62 & 1.13 & 0.59 & 0.22 \\
\hline
\end{tabular}

${ }^{a}$ Metal concentration in Polish soils $\mathrm{mg} \mathrm{kg}^{-1}$ d.w. (Regulation of the Minister of the Environment on September 2002 on the standards of the soil quality and ground quality 1.09.2002.)

b Metal concentration in plants $\mathrm{mg} \mathrm{kg}^{-1}$ d.w. (Ostrowska et al. 1991)

\section{Potentially toxic trace elements}

The concentrations of PTEs-potentially toxic trace elements-in soil samples were higher compared to their levels in grass, except $\mathrm{Cd}$ which was the other way around. Contamination with cadmium, higher in dried grass $\left(2.46 \mathrm{mg} \mathrm{kg}^{-1}\right)$ than in soil $\left(1.76 \mathrm{mg} \mathrm{kg}^{-1}\right)$, most likely originates not only from the ground but also from atmospheric dust falling directly on the plants. Plak et al. (2012) recorded a lower $\mathrm{Cd}$ content $\left(1.41 \mathrm{mg} \mathrm{kg}^{-1} \mathrm{dm}\right)$ in grass sward sampled at selected transport routes in Lublin.

In agricultural soils of China, contamination with cadmium was much lower than in the presented study, however, still exceeded the geochemical background and Chinese standards (CEPA 1995; Wei and Yang 2010; Zhang et al. 2015). Higher $\mathrm{Cd}$ content was recorded by Chahal et al. (2014) in India and by Micó et al. (2006) in Spain. Czech et al. (2014) also reported much lower concentration of this trace element in soil $\left(0.35 \mathrm{mg} \mathrm{kg}^{-1}\right)$ and plants $\left(0.7 \mathrm{mg} \mathrm{kg}^{-1}\right)$ of an agricultural commune in the Lesser Poland Province. These concentrations exceeded the allowable limits defined for fodder material by Kabata-
Pendias (2004) at the following values: $<100 \mathrm{mg} \mathrm{Zn}$, $<30 \mathrm{mg} \mathrm{Cu},<50 \mathrm{mg} \mathrm{Ni},<10 \mathrm{mg} \mathrm{Pb}$ and $<0.5 \mathrm{mg} \mathrm{Cd} \mathrm{kg}^{-1}$ $\mathrm{dm}$.

Cadmium shows variable soil concentrations dependent on the type of underlying host rock. Greater cadmium levels are also found in soils directly affected by pollution from human industrial activity. The metal shows high mobility at soil $\mathrm{pH}$ of 4.5-5.5, however, becomes immobilized as $\mathrm{pH}$ increases. In alkaline soils $(\mathrm{pH}>7.2)$, sorption of cadmium decreases as it is replaced with calcium and magnesium cations in the sorptive complex. In leaves, the element normally attains concentrations of $0.1-1 \mathrm{mg} \mathrm{kg}^{-1}$, while farm animals tolerate values up to $0.5 \mathrm{mg} \mathrm{kg}{ }^{-1}$. Absolute amounts of cadmium in soil are not always directly reflected in the metal content in plants. In humus-rich soils, ca. $75 \%$ of the element occurs in complexes with organic compounds (Weggler et al. 2004). Bioavailable cadmium present in the environment can be easily absorbed by organisms. In plants, the metal, though not necessary for their development, is assimilated through roots and leaves. In animals, after absorption in their digestive and, in part, respiratory tracts, cadmium forms 
Table 4 The diversity and density of taxonomic groups of pedofauna

\begin{tabular}{llc}
\hline Systematic groups & Trophic groups & Individual number $/ \mathrm{m}^{2}$ \\
\hline Enchytraeidae & $\mathrm{S}$ & 64 \\
Lumbricidae & $\mathrm{S}$ & 136 \\
Collembola & $\mathrm{S}$ & 9720 \\
Psychodidae larvae & $\mathrm{S}$ & 128 \\
Syrphidae larvae & $\mathrm{S}$ & 24 \\
Cecidomyiidae larvae & $\mathrm{Ph}$ & 152 \\
Thysanoptera & $\mathrm{Ph}$ & 8 \\
Homoptera & $\mathrm{Ph}$ & 40 \\
Carabidae larvae & $\mathrm{P}$ & 104 \\
Carabidae imago & $\mathrm{P}$ & 120 \\
Staphylinidae larvae & $\mathrm{P}$ & 64 \\
Staphylinidae imago & $\mathrm{P}$ & 152 \\
Dolochopodidae larvae & $\mathrm{P}$ & 16 \\
Formicidae & $\mathrm{P}$ & 120 \\
\hline
\end{tabular}

$S$ saprophag, $P h$ phytosaprophag, $P$ predator

protein complexes facilitating its transport and deposition. In the studied saprophagous invertebrates (Enchytraeidae, Lumbricidae, Collembola, Psychodidae larvae and Syrphidae larvae, Table 4), Cd content amounted to $19 \mathrm{mg} \mathrm{kg}^{-1}$ (Table 3).

In all cases, concentrations of $\mathrm{Cd}, \mathrm{Cu}$, and $\mathrm{Zn}$ were found to be within normal ranges. However, there was no evidence to suggest that plants were not adversely affected by elevated heavy metal concentrations. Under natural conditions, significant complexity of the environmental conditions makes it difficult to determine toxic concentrations and the adverse impact of heavy metals (Tomašević et al. 2004). Heavy metals are absorbed and translocated in plants through roots and exposed surfaces (leaves), making it difficult to discern the exact amount of elements uptaken from the soil or the air (Kabata-Pendias 2004; Serbula et al. 2013; Youning et al. 2014). As far as other metals are concerned, concentrations in soil were higher than in grass but lower than in animals (Table 3).

Concentrations observed for most metals exceeded the mean geochemical background of Polish soils (50 mg kg-1 for $\mathrm{Zn}$ ), however, did not exceed standard values defined in the Regulation of the Minister of Environment (2002). Zinc is a microelement required for plant development and growth. Accumulation of the metal increases if it occurs in excess amounts in the environment, as it may be assimilated and deposited by plants, mainly in their roots. Natural content of zinc in plants varies between 15 and $150 \mathrm{mg} \mathrm{kg}^{-1} \mathrm{dm}$ (Ostrowska et al. 1991). In the analyzed grass sward, $\mathrm{Zn}$ attained a high mean value of $103 \mathrm{mg} \mathrm{kg}^{-1} \mathrm{dm}$. In a study by Plak et al. (2012), zinc levels showed low variability and a mean of $133.4 \mathrm{mg} \mathrm{kg}^{-1}$. In India, $\mathrm{Zn}$ content in arable soil varied between 73 and $320 \mathrm{mg} \mathrm{kg}^{-1}$ (Chahal et al. 2014) while in Spain it ranged from 33.4 to $80.7 \mathrm{mg} \mathrm{kg}^{-1}$ (Micó et al. 2006).

Estimation of $\mathrm{Pb}$ has attracted a large attention worldwide due to its severe toxicity. The level of lead contamination of agricultural soils in India was higher than in presented research (Chahal et al. 2014). At the same time lower concentration of $\mathrm{Pb}$ in farmland soils of Tanzania was detected by Machiwa (2010) and in agricultural soils of Spain by Micó et al. (2006). Natural concentrations of lead in plants range from 1 to $5 \mathrm{mg} \mathrm{kg}^{-1} \mathrm{dm}$. Typically, they are less than $10 \mathrm{mg} \mathrm{kg}^{-1}$ (Padmavathiamma et al. 2007). These values were exceeded in the present study, where the metal was recorded at $28 \mathrm{mg} \mathrm{kg}^{-1}$ (Table 3).

Physiological functions of nickel have still not been well established; however, it most likely has a toxic effect on metabolic processes. In topsoil, total content of $\mathrm{Ni}$ may vary broadly, however most frequently amounts to 4-50 $\mathrm{mg} \mathrm{kg}^{-1}$. In the herein study, the metal attained a mean concentration of $23 \mathrm{mg} \mathrm{kg}^{-1}$. Similar result of $\mathrm{Ni}$ concentration was observed in agricultural soils in Algieria and India (Chahal et al. 2014; Kebir and Bouhadjera 2011), while in European farm soils Lado et al. (2008) detected very high range of $\mathrm{Ni}\left(1-2565 \mathrm{mg} \mathrm{kg}^{-1}\right)$. Soil nickel in mobile forms, may permeate into plants, where it also shows high mobility and is easily translocated to the overground parts.

Soil copper occurs in various forms, however, usually of low mobility, such as carbonate and sulfate precipitations, and is strongly absorbed by organic matter and clayey minerals. Availability of copper is $\mathrm{pH}$ dependent and increases with lower soil $\mathrm{pH}$. Only a small part of total $\mathrm{Cu}$ content is represented by its accessible forms.

Maximum concentration of copper in studied soil sample was found to be $17 \mathrm{mg} \mathrm{kg}^{-1}$. $\mathrm{Cu}$ concentration was found less than permissible value $\left(150 \mathrm{mg} \mathrm{kg}^{-1}\right)$ defined in the Regulation of the Minister of Environment (2002). Some of reports have documented high content of $\mathrm{Cu}$ in agricultural lands (Kebir and Bouhadjera 2011; Machiwa 2010).

Mean concentrations of potentially toxic trace elements in the extracted soil fauna decreased in the following order: $\mathrm{Zn}>\mathrm{Pb}>\mathrm{Cu}>\mathrm{Ni}>\mathrm{Cd}$. A slightly different pattern: $\mathrm{Zn}>\mathrm{Cu}>\mathrm{Mn}>\mathrm{Pb}>\mathrm{Cd}$, was arrived at by Butovsky (2011) in studies of soil carabid beetles. Heikens et al. (2001) ranked taxonomic groups of terrestrial invertebrates according to metal accumulation. Van Straalen et al. (2001) reported high concentrations of $\mathrm{Cd}$ and $\mathrm{Pb}$ in ground beetles, oribatid mites, and earthworms and low concentrations in springtails, centipedes, and spiders near a metallurgical factory. Comparative studies of metal accumulation in bodies of invertebrates, representing various trophic groups and collected at vicinities of large pollutant emitters, have 
shown that levels of cadmium, copper and lead are greater in predators and saprovores than in herbivores (Jelaska et al. 2007).

\section{Bioconcentration factor}

Most frequently, plants assimilate trace elements according to a specific gradient, including strong $(\mathrm{Cd})$, moderate $(\mathrm{Zn}$, $\mathrm{Cu}$ and $\mathrm{Pb}$ ) and poor (Ni) accumulation (Kaszubkiewicz and Kawałko 2009). A similar accumulation pattern has been observed in the present study (Table 5). Some trace elements evidently tend to accumulate in plants, as indicated by the bioconcentration factor (BCF), showing the greatest value of 1.42 for $\mathrm{Cd}$ and not exceeding 1 in other metals (Table 5). Much higher values, of as much as 10, were recorded for the bioaccumulation and phytoaccumulation factor of cadmium by Maciołek et al. (2013). Bioaccumulation factor obtained by Czech et al. (2014) for $\mathrm{Cd}$ (2.0), $\mathrm{Zn}$ (1.34) and $\mathrm{Cu}(0.8)$ was also greater than in the presented study. $\mathrm{Cd}$ and $\mathrm{Zn}$ show an antagonistic relationship, very often indicated by lower absorption of $\mathrm{Cd}$ by plants at higher $\mathrm{Zn}$ content in the environment as well as by lower $\mathrm{Zn}$ concentrations in plants assimilating great amounts of $\mathrm{Cd}$.

Similar relations were observed in the presented research (Table 5). In terrestrial invertebrates, the relationship between total heavy metal soil content and the internal metal content in invertebrates tends to be strong in

Table 5 Summary statistics of bioconcentration factor values (BCF) of the potentially toxic trace elements $\left(\mathrm{mg} \mathrm{kg}^{-1}\right)$ in grass and soil fauna (number of samples $=12$ )

\begin{tabular}{llrlll}
\hline Elements & $\mathrm{Pb}$ & \multicolumn{1}{l}{$\mathrm{Cd}$} & $\mathrm{Ni}$ & $\mathrm{Zn}$ & $\mathrm{Cu}$ \\
\hline BCF grass $^{\mathrm{a}}$ & & & & & \\
Mean & 0.54 & 1.42 & 0.52 & 0.65 & 0.69 \\
Min & 0.42 & 1.01 & 0.46 & 0.49 & 0.55 \\
Max & 0.68 & 1.88 & 0.71 & 0.84 & 0.93 \\
Standard deviation & 0.08 & 0.32 & 0.09 & 0.15 & 0.14 \\
Median & 0.53 & 1.45 & 0.48 & 0.64 & 0.64 \\
Skewness coefficient & 0.41 & 0.09 & 1.91 & 0.24 & 1.19 \\
BCF fauna & \\
Mean & & & & & \\
Min & 1.37 & 11.17 & 1.63 & 4.46 & 2.48 \\
Max & 0.51 & 4.92 & 0.61 & 3.17 & 1.38 \\
Standard deviation & 0.78 & 5.49 & 1.27 & 0.75 & 0.82 \\
Median & 1.23 & 10.97 & 1.15 & 4.49 & 2.45 \\
Skewness coefficient & 0.56 & 1.16 & 1.60 & -0.80 & 0.18 \\
\hline
\end{tabular}

${ }^{\mathrm{a}} \mathrm{BCF}$ grass $=$ metal in grass in $\mathrm{mg} \mathrm{kg}^{-1} \mathrm{~d} . \mathrm{w} . /$ metal in soil $\mathrm{mg} \mathrm{kg}^{-1}$ d.w

b $\mathrm{BCF}$ fauna $=$ metal in fauna $\mathrm{mg} \mathrm{kg}^{-1} \mathrm{~d} . \mathrm{w} . / \mathrm{metal}$ in soil $\mathrm{mg} \mathrm{kg}^{-1}$ d.w the order of $\mathrm{Pb}>\mathrm{Cd}>\mathrm{Cu}, \mathrm{Zn}$ (Heikens et al. 2001). It has been speculated that in terrestrial invertebrates $\mathrm{Cu}$ and $\mathrm{Zn}$ can be regulated to a certain degree, resulting in a constant body concentration over a range of soil contents (Heikens et al. 2001; Notten et al. 2005; Santorufo et al. 2012). Notten et al. (2005) in their study suggested, that metal transfer from polluted leaves (Urtica dioica) was more important than transfer from the soil to Cepaea nemoralis snails.

In the investigated meadow, both grass cover and the extracted soil fauna accumulated cadmium in largest amounts and incorporated the studied metals in the following order: $\mathrm{Cd}>\mathrm{Zn}>\mathrm{Cu}>\mathrm{Ni}>\mathrm{Pb}$ (Table 5). All considered elements showed greater concentrations (nearly tenfold higher for cadmium) in fauna than grasses. The Spearman correlation coefficient was calculated to assess relationships between concentrations of particular metals in soil. A statistically significant correlation has been established between $\mathrm{Zn}$ and $\mathrm{Ni}$ soil concentrations $(R=0.94)$. Content of other metals was not correlated (Table 6). In soil fauna and grasses, metal levels showed normal distribution; therefore, their correlation was tested with the Pearson correlation coefficient. A positive correlation was observed between cadmium and nickel concentrations in soil fauna $(R=0.91)$ (Table 6). Statistically significant positive correlation was also recorded between $\mathrm{Zn}$ concentration in soil and soil fauna $(R=0.85, p=0.033)$. No other significant relationships have been found between metal levels in soil and fauna, soil and grass or fauna and grass (Table 7).

As reported by Wojciechowska et al. (2010), in the last years environmental pollution with lead has noticeably decreased and presently cadmium has become the element imposing greatest threat to human health. The concentrations of potentially toxic trace elements in soil samples were higher compared to their levels in grass, except $\mathrm{Cd}$ which is the other way around. In agricultural soils, $54 \%$ of $\mathrm{Cd}$ originates from phosphate fertilizers, $5 \%$ from sewage and $41 \%$ from atmospheric air. Cadmium remains in soil, particularly its humus, for many years, in forms easily accessible to plants. Therefore, in such areas it is important to control the content of metal both in the soil and its fauna.

\section{Conclusions}

Test results indicate a potential threat of contamination with potentially toxic trace elements, especially cadmium, in the agricultural areas located next to transportation routes. In our tests, cadmium showed the highest rate of accumulation in plants and in bodies of soil animals, which is attributable to its bioavailability and easy absorption by 
Table 6 Significant differences between the concentration of $\mathrm{Pb}, \mathrm{Cd}, \mathrm{Zn}, \mathrm{Cu}, \mathrm{Ni}$ in soil, soil fauna and grass

\begin{tabular}{|c|c|c|c|c|c|c|c|}
\hline \multirow[t]{2}{*}{ Metal vs metal } & \multirow[t]{2}{*}{$N$} & \multicolumn{2}{|l|}{ Soil } & \multicolumn{2}{|l|}{ Grass } & \multicolumn{2}{|c|}{ Soil fauna } \\
\hline & & $R$ & $p$ & $R$ & $p$ & $R$ & $p$ \\
\hline $\mathrm{Zn}$ vs $\mathrm{Cu}$ & 12 & 0.09 & 0.872 & 0.36 & 0.474 & 0.13 & 0.798 \\
\hline $\mathrm{Zn}$ vs Ni & 12 & 0.94 & $0.005 * *$ & 0.32 & 0.532 & -0.58 & 0.225 \\
\hline $\mathrm{Zn}$ vs $\mathrm{Cd}$ & 12 & -0.37 & 0.468 & 0.44 & 0.376 & -0.74 & 0.095 \\
\hline $\mathrm{Zn}$ vs $\mathrm{Pb}$ & 12 & -0.03 & 0.957 & -0.06 & 0.904 & -0.37 & 0.471 \\
\hline $\mathrm{Cu}$ vs $\mathrm{Ni}$ & 12 & 0.14 & 0.787 & -0.01 & 0.988 & 0.68 & 0.134 \\
\hline $\mathrm{Cu}$ vs $\mathrm{Cd}$ & 12 & 0.09 & 0.872 & 0.36 & 0.485 & 0.55 & 0.256 \\
\hline $\mathrm{Cu}$ vs $\mathrm{Pb}$ & 12 & 0.66 & 0.156 & 0.38 & 0.460 & 0.46 & 0.359 \\
\hline $\mathrm{Ni}$ vs $\mathrm{Cd}$ & 12 & -0.09 & 0.872 & 0.11 & 0.835 & 0.91 & 0.013* \\
\hline $\mathrm{Ni}$ vs $\mathrm{Pb}$ & 12 & 0.09 & 0.872 & -0.55 & 0.258 & 0.73 & 0.102 \\
\hline $\mathrm{Cd}$ vs $\mathrm{Pb}$ & 12 & -0.03 & 0.937 & 0.12 & 0.822 & 0.53 & 0.281 \\
\hline
\end{tabular}

Numbers in bold indicate a significant correlation

$* 0.05>p>0.01 ; * * 0.01>p>0.001 ; p>0.05$-no significant differences

Table 7 Correlation coefficient $R$ and $p$ value between the concentration of potentially toxic trace elements (PTEs) in soil, grass and soil fauna

\begin{tabular}{|c|c|c|c|c|c|c|c|}
\hline \multirow[t]{2}{*}{ PTEs } & \multirow[t]{2}{*}{$\mathrm{N}$} & \multicolumn{2}{|c|}{ PTEs in soil vs PTEs in grass } & \multicolumn{2}{|c|}{ PTEs in soil vs PTEs in soil fauna } & \multicolumn{2}{|c|}{ PTEs in grass vs PTEs in soil fauna } \\
\hline & & $R$ & $p$ & $R$ & $p$ & $R$ & $p$ \\
\hline $\mathrm{Zn}$ & 12 & -0.15 & 0.781 & 0.85 & 0.033* & -0.60 & 0.203 \\
\hline $\mathrm{Cu}$ & 12 & 0.14 & 0.787 & -0.03 & 0.957 & -0.43 & 0.397 \\
\hline $\mathrm{Ni}$ & 12 & -0.01 & 0.978 & -0.68 & 0.135 & 0.72 & 0.107 \\
\hline $\mathrm{Cd}$ & 12 & 0.30 & 0.559 & -0.03 & 0.956 & 0.18 & 0.731 \\
\hline $\mathrm{Pb}$ & 12 & -0.03 & 0.957 & 0.37 & 0.468 & -0.43 & 0.397 \\
\hline
\end{tabular}

Numbers in bold indicate a significant correlation

$* 0.05>p>0.01 ; p>0.05$-no significant differences

organisms. Thereby, it poses hazard to all elements of the trophic chain. Therefore, monitoring for cadmium content in the environment is critical. In addition, agricultural production should be banned in the areas adjacent to the road.

Open Access This article is distributed under the terms of the Creative Commons Attribution 4.0 International License (http://crea tivecommons.org/licenses/by/4.0/), which permits unrestricted use, distribution, and reproduction in any medium, provided you give appropriate credit to the original author(s) and the source, provide a link to the Creative Commons license, and indicate if changes were made.

\section{References}

Aelion CM, Davis HT, McDermott S, Lawson AB (2009) Soil metal concentrations and toxicity: associations with distances to industrial facilities and implications for human health. Sci Total Environ 407:2216-2223

Ayodele JT, Oluyomi CD (2011) Grass contamination by trace metals from road traffic. J Environ Chem Ecotoxicol 3:60-67

Boshoff M, De Jonge M, Scheifler R, Bervoets L (2014) Predicting $\mathrm{As}, \mathrm{Cd}, \mathrm{Cu}, \mathrm{Pb}$ and $\mathrm{Zn}$ levels in grasses (Agrostis sp. and Poa sp.) and stinging nettle (Urtica dioica) applying soil-plant transfer models. Sci Total Environ 493:862-871
Bur T, CrouauY BiancoA, GandoisL ProbstA (2012) Toxicity of $\mathrm{Pb}$ and of $\mathrm{Pb} / \mathrm{Cd}$ combination on the springtail Folsomia candidain natural soils: reproduction, growth and bioaccumulation as indicators. Sci Total Environ 414:187-197

Butovsky RO (2011) Heavy metals in carabids (Coleoptera, Carabidae). Zookeys 100:215-222. doi:10.3897/zookeys.100.1529

Carlon CD, Alessandro M, Swartjes F (2007) Derivation methods of soil screening values in Europe. A review and evaluation of national procedures towards harmonisation. In: Carlon C (ed) JRC Scientific and Technical Report EUR 22805 EN-2007. Office for Official Publications of the European Communities, Luxemburg

CEPA (1995) Chinese Environmental Protection Administration, environmental quality standard for soils (GB15618-1995), Beijing

Chahal V, Chand P, Nagpal A, Katnoria JK, Pakade YB (2014) Evaluation of heavy metals contamination and its genotoxicity in agricultural soil of Amritsar, Punjab, India. Int J Res Chem Environ 4:20-28

Czech T, Baran A, Wieczorek J (2014) Content of heavy metals in soil and plants from an area Borzęcin municipality (Malopolska Province). Ecol Eng 37:89-98

Dalenberg JW, Driel JV (1990) Contribution of atmospheric deposition to heavy metals concentration in field crops. Neth J Agr Sci 38:369-379

Heikens A, Peijenburg WJGM, Hendriks AJ (2001) Bioaccumulation of heavy metals in terrestrial invertebrates. Environ Pollut 113:385-393 
Holoubek I, Dušek L, Sáňka M, Hofman J, Čupr P, Jarkovskỳ J, Zbíral J, Klánová J (2009) Soil burdens of persistent organic pollutants-their levels, fate and risk. Part I. Variation of concentration ranges according to different soil uses and locations. Environ Pollut 157:3207-3217

Hooda PS (2010) Introduction, in trace elements in soils (ed Hooda PS). Wiley, Chichester

Jelaska LŠ, Blanuša M, Durbešić P, Jelaska SD (2007) Heavy metal concentrations in ground beetles, leaf litter, and soil of a forest ecosystem. Ecotoxicol Environ Safe 66:74-81

Kabata-Pendias A (2011) Trace elements in soils and plants. CRC Press, Boca Raton, London, New York, Washington, D.C.

Kabata-Pendias A (2004) Soil-plant transfer of trace elements-an environmental issue. Geoderma 122:143-149

Kabata-Pendias A, Mukherjee AB (2007) Trace elements from soil to human. Springer, Berlin Heidelberg

Kaszubkiewicz J, Kawałko D (2009) Total content of heavy metals in soils and plants at the area of Jelenia Góra district. Environ Prot Nat Resour 40:177-189

Kebir T, Bouhadjera K (2011) Heavy metal concentrations in agricultural soils and accumulation in plants growing near of dumpsite of Ghazaouet (west of Algeria). Int J Curr Res 2:42-49

Kelepertzis E (2014) Accumulation of heavy metals in agricultural soils of Mediterranean: insights from Argolida basin, Peloponnese, Greece. Geoderma 221-222:82-90

Lado LR, Hengl T, Reuter HI (2008) Heavy metals in European soils: a geostatistical analysis of the FOREGS geochemical database. Geoderma 148:189-199

Machiwa JF (2010) Heavy metal levels in paddy soils and rice (Oryza sativa) from wetlands of lake Victoria basin. Tanz J Sci 36:59-72

Maciołek H, Zielińska A, Domarecki T (2013) The geobiologicalchemical effect of cadmium and lead on the natural environment. J Ecol Health 17(2):63-71

Maliszewska-Kordybach B, Smreczak B, Klimkowicz-Pawlas A (2013) Zagrożenie zanieczyszczeniami chemicznymi gleb na obszarach rolniczych w Polsce w świetle badań IUNG-PIB w Puławach. STUDIA i RAPORTY IUNG-PIB 35(9):97-118

Martínez-López S, Martínez-Sánchez MJ, Pérez-Sirvent C, Bech J, Gómez Martínez MC, García-Fernandez AJ (2014) Screening of wild plants for use in the phytoremediation of mining-influenced soils containing arsenic in semiarid environments. J Soil Sediment 14:794-809

Micó C, Peris M, Sánchez J, Recatalá L (2006) Heavy metal content of agricultural soils in a Mediterranean semiarid area: the Segura River Valley (Alicante, Spain). Span J Agric Res 4:363-372

Murphy PW (1962) Extraction methods for soil animals. 1. Dynamic methods with particular reference to funnel processes. In: Murphy PW (ed) Progress in soil zoology. Butterworth, London

Niesiobędzka K (2012) Transfer of copper, lead and zinc in soil-grass ecosystem in aspect of soils properties, in Poland. Bull Environ Contam Toxicol 88(4):627-633

Notten MJM, Oosthoek AJP, Rozema J, Aerts R (2005) Heavy metal concentrations in a soil-plant-snail food chain along a terrestrial soil pollution gradient. Environ Pollut 138:178-190
Ostrowska A, Gawliński S, Szczubiałka Z (1991) Metody analizy i oceny właściwości gleb i roślin. Instytut Ochrony Środowiska, Warszawa

Padmavathiamma PK, Loretta Y, Li LY (2007) Phytoremediation technology: hyper-accumulation metals in plants. Water Air Soil Poll 184:105-126

Plak A, Bartmiński P, Lata L, Dębicki R (2012) Accumulation of heavy metals in plants from areas in the vicinity of the main thoroughfares of Lublin. In: Proceedings of ECOpole, vol 6, pp 261-265. doi:10.2429/proc.2012.6(1)035

Regulation of the Minister of the Environment (2002) Standards of the soil quality and ground quality 1.09.2002. Dziennik Ustaw, $\mathrm{Nr}$ 165, 1359 (in Polish)

Santorufo L, Van Gestel CAM, Rocco A, Misto G (2012) Soil invertebrates as bioindicators of urban soil quality. Environ Pollut 161:57-63

Serbula SM, Tanja S, KalinovicTS Ilic AA, Jelena V, Kalinovic JV, Steharnik MM (2013) Assessment of airborne heavy metal pollution using Pinus spp. and Tilia spp. Aerosol Air Qual Res 13:563-573. doi:10.4209/aaqr.2012.06.0153

Siebielec G, Smreczak B, Klimowicz-Pawlas A, MaliszewskaKordybach B, Terelak H, Koza P, Łysiak M, Gałązka R, Pecio M, Miturski T, HryńczukB (2013) Monitoring chemizmu gleb ornych w Polsce latach 2010-2012. Biblioteka Monitoringu Środowiska, Warszawa (in Polish)

Soil Quality Standards for Trace Elements (2011) Derivation, implementation and interpretation. In: Merringtonand G, Schoeters I (eds) CRC Press, Boca Raton, London, New York

Sokal RR, Rohlf FJ (1995) Biometry: the principles and practices of statistics in biological research. W. H. Freeman and Company, New York

Tomašević M, Rajšić S, Dordević D, Tasić M, KrstićJ Novaković V (2004) Heavy metals accumulation in tree leaves from urban areas. Environ Chem Lett 2:151-154

Van Straalen M, Butovsky RO, Pokarzhevskii AD, Zaitsev AS, Verhoef CS (2001) Metal concentrations in soil and in invertebrates in the vicinity of a metallurgical factory near Tula (Russia). Pedobiologia 45:451-466

Weggler K, McLaughlin MJ, Graham RD (2004) Heavy metals in the environment. Effect of chloride in soil solution on the plant availability of biosolid-bornecadmium. J Environ Qual 33:496-504

Wei B, Yang L (2010) A review of heavy metal contaminations in urban soils, urban road dusts and agriculture soils from China. Microchem J 94:99-107

Wojciechowska-Mazurek M, Mania M, Starska K, Opoka M (2010) Cadmium in foodstuffs-purposefulness of decreasing of the prevailing limits. Food Industry 2:45-48

Youning Hu, Wang Dexiang, Wei Lijing, Zhang Xinping, Song Bin (2014) Bioaccumulation of heavy metals in plant leaves from Yan'an city of the Loess Plateau, China. Ecotox Environ Safe 110:82-88

Zhang X, Chen D, Zhong T, Zhang X, Cheng M, Li X (2015) Assessment of cadmium $(\mathrm{Cd})$ concentration in arable soil in China. Environ Sci Pollut Res 22:4932-4941. doi:10.1007/ s11356-014-3892-6 